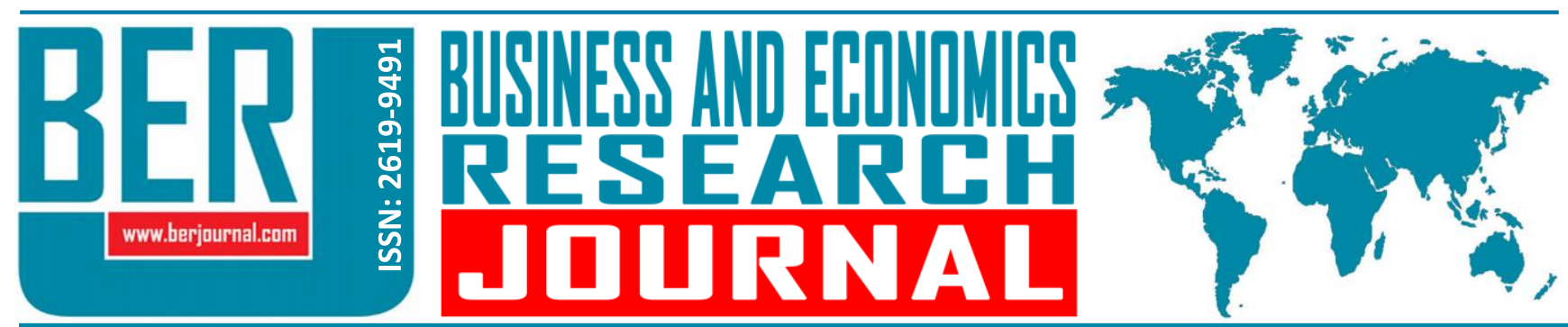

Business and Economics Research Journal Vol. 12, No.2, $2021 \quad$ pp. 359-368

doi: 10.20409/berj.2021.326

\title{
Beta Herding in the Covid-19 Era: Evidence from Borsa Istanbul
}

\section{Hilal H. Erdogan ${ }^{a}$}

Abstract: The study aims to examine beta herding in the Covid-19 era in Borsa Istanbul. Herding was analyzed based on the state-space model utilizing cross-sectional volatility of beta coefficients between January 2010 and November 2020. The results provided evidence of herding in Borsa Istanbul. In case of beta herding, this model provides to detect whether herding is intentional or spurious, as well. Within this context, market volatility, market return, size, and value factors of the Fama-French model were included in the analysis. Accordingly, intentional herding was found in Borsa Istanbul and investors tend to herd more, particularly under the global pandemic of Covid-19.
Keywords: Herd Behavior, Covid-19, Cross-Sectional Volatility, Beta Coefficient, Borsa Istanbul

JEL: G01, G10, G41

$\begin{array}{ll}\text { Received } & : 16 \text { December } 2020 \\ \text { Revised } & : 08 \text { March } 2021 \\ \text { Accepted } & : 19 \text { April } 2021 \\ & \\ \text { Type } & \text { : Research }\end{array}$

\section{Introduction}

The pandemic of Coronavirus disease (Covid-19) which emerged from Central China towards the end of December 2019 has dramatically affected stock markets all over the world. Topcu and Gulal (2020) have reported that stock markets have reacted to the pandemic by early March when the pandemic spread to more than 200 countries. Even if all the countries have made forceful efforts to save their economies, it has started to pose a risk for them in a very short time (Calap, 2021). He et al. (2020) describe the Covid-19 pandemic as a "Black Swan" which relates to an unpredictable event while Asiltürk (2021) defines the Covid19 pandemic as an unexpected crisis that markets hardly ever met before. Under these circumstances, the pandemic is perceived as a great threat to the stock markets and investors tend to exhibit their behaviors with feelings of panic and stress. Therefore, they would not be fully rational and would be affected by their sentiment during the decision-making process, contrary to the efficient market hypothesis (Shleifer \& Summers, 1990).

There have been several large market events and large deviations that cast doubt on the basic assumptions of the efficient market hypothesis (Ritter, 2003: 429). For instance, stock prices and land prices of Japanese corporations grew dramatically from 1986 to 1988 and declined dramatically from 1989 to 1992 during the Japanese stock price and land price bubble (Stone \& Ziemba, 1993: 149). A severe and unexpected decline in stock prices also occurred in 1987 (Carlson, 2006: 1). As similar, a rapid economic crash came in Taiwan Stock Market in early 1990 (Chen, 2001: 215). Economists could not have rationally explained these market events. They have emphasized that the dramatic drops in market prices can only be explained by psychological factors, as the fundamental elements of the economy do not change rapidly over that period 
(Malkiel, 2003: 73-74). Montier (2002) suggests that market efficiency may not be the best paradigm for evaluating financial systems. Hence the foundations of corporate finance need to be rebuild from a behavioral standpoint. Behavioral finance is a new approach that has developed as a reaction to these unexpected events (Barberis \& Thaler, 2003: 1053). From this point of view, behavioral finance has placed a focus on investor psychology and stock market anomalies leading to inefficiency and irrationality (Baker \& Wurgler, 2006).

This study provides a comprehensive perspective on herd behavior which seems such an anomaly that is defined as following other investors' trading activities. Christie and Huang (1995: 32) emphasize that investors prefer not to make decisions based on their own beliefs and tend to imitate the others, in particular, during periods of market stress. Consistently, Barber and Odean (2007) point out that investors select to buy the stock which attracts the others' attention at most. However, investors acting as a herd may only reflect their perception of identical fundamental information, if the herding is spurious (Zhou \& Lai, 2009: 391). Hence, an intentional element has to be taken into account to evaluate herding better. Moreover, herd behavior is crucial under uncertain and risky conditions for decision-making process and the examination of herding in crisis periods provides valuable information. Furthermore, many researchers have proved that investors herd more in developing markets than developed markets (Christie \& Huang, 1995; Wermers, 1999; Chang et al. 2000; Chen et al., 2003; Hwang \& Salmon, 2004). Chen et al. (2003) argue that low availability and accuracy of information are the reasons for herding in developing stock markets. Severe and unexpected movements may also emerge because of the political and economic instability in developing stock markets. Consistently, Wang (2008) explains why herding is observed more in developing markets by information acquisition. Because accessing information is time-consuming and expensive in developing markets, instead, making a decision based on other investors' decisions is relatively cheap and easy.

Within this context, it is worth examining whether financial actors take into account herd behavior while making decisions, particularly, in developing markets. Thus, this study aims to find out the presence of beta herding in Borsa Istanbul under the global pandemic of Covid-19. The state-space model employing cross-sectional volatility of beta coefficients was conducted to examine whether herding is intentional, as well. To measure whether there is intentional effect on herd behavior, market volatility, market return, and Fama-French factors such as size and book-to-market ratio were included in the analysis. Daily stock returns traded on Borsa Istanbul were used covering the periods from January 2010 to November 2020. The results supported existence of herd behavior among investors trading on Borsa Istanbul and stronger evidence of herding was found especially for the pandemic period, in contrast with no pandemic and whole periods. It was also found that herd behavior detected by the cross-sectional volatility of beta coefficients could be explained by intentional herding. Thus, investors herd after observing others, rather than following the public information. The results of this study also indicated consistency with the argument that investors may tend to follow the market trend more in a developing market.

Although herd behavior was investigated in many studies in Borsa Istanbul, the studies using beta herding are quite limited. Even if this method was used, market fundamentals such as market return and market volatility and size and book-to-market ratio within Fama-French factors were not included at most. Hence, this study is one of the first comprehensive attempts to examine intentional herd behavior in Borsa Istanbul by including these factors. However, there is also a gap within the methodology of cross-sectional volatility of beta coefficients in Borsa Istanbul, especially during crisis periods. Therefore, this study is important as being the first study in the literature to detect herding in Borsa Istanbul in the Covid-19 era.

This study provides the literature review on herd behavior, at first. Then, data is covered and methodology based on the state-space model is explained. At last, empirical findings are discussed.

\section{Literature Review}

To capture herd behavior, the state-space model utilizing the cross-sectional volatility of beta coefficients was employed for different periods within different stock markets. Within the methodology, Seetharam and Britten (2013) tested the existence of beta herding among investors between 1995 and 2011 
in South Africa. The results provided the absence of herd behavior for up markets but provided significant herd behavior for down markets. In Turkey, Altay (2008) utilized this method to detect herd behavior in the 1997-2008 period. Daily data indicated an existence of herding during up and down market movement days. On the other hand, Demir et al. (2014) investigated herd behavior in Borsa Istanbul in the 2000-2011 period. Monthly data provided evidence of herding, supporting Altay (2008). On the contrary, Solakoglu and Demir (2014) used the model following Hwang and Samon (2004) to examine herd behavior in BIST 30 index and Second National Market (SNM) for the period from 2000 to 2013 and provided the existence of herding in SNM while herding was not observed in BIST 30. Pop (2012) measured herd behavior through state-space model by using weekly excess returns between 2003 and 2012 in Romania. Differently, market volatility and macroeconomic factors were utilized and it was found that herding was observed less during the market stress days. Macroeconomic variables were also taken to examine herd behavior in the study of Messis et al. (2014). The results of state-space model supported the existence of herding. Özsu (2015) tested the presence of herding by employing cross-sectional volatility of the betas and resulted that investors follow the others more in session two market in Borsa Istanbul.

Crisis periods are also aroused considerable interest in herding studies. Caporale et al. (2008) detected herd behavior in the Athens Stock Market and herding was observed during the stock market crisis. Other studies measuring the presence of herd behavior during the financial crisis were conducted by Ourda et al. (2013) and Angela-Maria et al. (2015) in European stock markets and both of the studies provided herding. Herd behavior was also observed during the the Asian crisis, in the study of Ourda et al. (2013). Similarly, Lai and Lau (2004) tested investors' behavior in Malaysia during Asian crisis and supported the existence of herding in down markets while no evidence was observed for up markets. Argentine crisis period was included in the study of Gavriilidis et al. (2007). They analyzed herd behavior by using the state-space model between 2000 and 2006 and provided evidence of herd behavior in the Argentina stock market. In Turkey, Durukan et al. (2017) used state-space model and detected an increased herd behavior during the global financial crisis. Akçaalan et al. (2020) investigated beta herding in Borsa Istanbul between 2001 and 2016. They found that investors do not imitate others during economic crisis periods, instead exhibiting herding under the political instability.

Differently, Wang (2008) included Fama-French factors to detect intentional herding and conducted a study for developed and developing markets, separately. He used monthly stock returns between 1985 and 2005. Accordingly, higher herding was observed in developing markets than developed markets. Hassairi and Viviani (2011) also used Fama-French factors for European stock markets. Herding was observed in all countries, except market turmoil and crisis periods, supporting the study of Hwang and Salmon (2004). Accordingly, investors exhibited herd behavior more in risky conditions.

To sum up, herd behavior attracts the attention of the researchers over the last two decades, and the state-space model suggested by Hwang and Salmon (2004) is preferred to use to detect herding in different stock markets. Based on the earlier studies, it can be said that investors tend to herd more under risky market conditions rather than normal market conditions and herd behavior is observed more in developing markets.

\section{Data and Methodology}

In this study, the presence of intentional herding was detected by using cross-sectional volatility of beta coefficients, as suggested by Hwang and Salmon (2004). Daily stock returns were utilized between $4^{\text {th }}$ January 2010 and $30^{\text {th }}$ November 2020 and BIST 100 Index was taken as a market proxy.

Daily closing prices were obtained from Borsa Istanbul official website and converted to logarithmic stock returns, as follows:

$$
R_{i t}=\ln \left(P_{i t} / P_{i t-1}\right)
$$

where $R_{i t}$ is the stock return on day $t$ and $P_{i t}$ is the closing price of $i$ stock on day $t$. 


\subsection{Beta Herding Model}

To be analyzed within the methodology of cross-sectional volatility, beta coefficients were used in the analysis and were estimated by using Equation 2:

$$
E_{t}\left(r_{i t}\right)=\beta_{i m t} E_{t}\left(r_{m t}\right)
$$

where $r_{i t}$ is the excess stock return on day $t, r_{m t}$ is the excess market return on day $t$. Additionally, $\beta_{i m t}$ represents the systematic risk measure.

The excess returns on stock $i$ were calculated by using stock returns and the risk-free rate $\left(r_{f}\right)$. To estimate risk-free rate, yearly compounded interest rates of treasury discounted auctions were included in the analysis and converted to daily interest rates. Yearly compounded interest rates of treasury discounted auctions were obtained from Undersecretariat of Treasury official website.

As in Hwang and Salmon (2004), the cross-sectional standard deviation of the beta coefficients was estimated by utilizing Equation 3, as follows:

$$
\operatorname{Std}_{c}\left(\beta_{i m t}^{b}\right)=\sqrt{\frac{\sum_{i=1}^{N_{t}}\left(\beta_{i m t}^{b}-\overline{\beta_{l m t}^{b}}\right)^{2}}{N_{t}}}
$$

where $\overline{\beta_{t m t}^{b}}=\frac{1}{N_{t}} \sum_{i=1}^{N_{t}} \beta_{i m t}^{b}$.

To determine the level of herding over time, at first, logarithms of $\log \left[\operatorname{Std}_{c}\left(\beta_{i m t}^{b}\right)\right]$ equation were estimated and then Equation 4 was constructed:

$$
\begin{aligned}
& \log \left[\operatorname{Std}_{c}\left(\beta_{i m t}^{b}\right)\right]=\mu_{m}+H_{m t}+v_{m t} \\
& H_{m t}=\emptyset_{m} H_{m t-1}+\mathrm{y}_{m t}
\end{aligned}
$$

where the $\log \left[\operatorname{Std}_{c}\left(\beta_{i m t}^{b}\right)\right]$ represents the measurement equation, the Equation 5 of $H_{m t}$ represents the transition equation and $\mathrm{y}_{m t} \sim \operatorname{iid}\left(0, \sigma_{m \eta}^{2}\right)$.

To extract $H_{m t}$, the standard state-space model was conducted by utilizing Kalman Filter. The statespace model was explained by using Kalman Filter suggested by Kalman (1960) and developed by Kalman and Bucy (1961), as follows:

$$
\begin{aligned}
& Y_{t}=c+S X_{t}+\varepsilon_{t} \\
& X_{t}=d+H X_{t-1}+z_{t}
\end{aligned}
$$

where $Y_{t}$ is the measurement equation at time $t, X_{t}$ is the transition equation at time $t . c$ and $d$ are constants, $\varepsilon_{t}$ is the measurement error and $z_{t}$ is the state error.

In the existence of herd behavior, $H_{m t}$ is expected to be significant. Under the circumstances, the magnitude of $H_{m t}$ shows the level of herd behavior. Therefore, if $H_{m t}=1$, it can be concluded that perfect herding is found.

\subsubsection{Beta Herding Model with Market Volatility and Market Return}

To examine whether herd behavior observed in Borsa Istanbul was intentional, market volatility and market return were taken into consideration and the following Equation 8 was estimated: 


$$
\begin{aligned}
& \log \left[\operatorname{Std}_{c}\left(\beta_{i m t}^{b}\right)\right]=\mu_{m}+H_{m t}+c_{m 1} \log \sigma_{m t}+c_{m 2} r_{m t}+v_{m t} \\
& H_{m t}=\emptyset_{m} H_{m t-1}+\eta_{m t}
\end{aligned}
$$

where $\log \sigma_{m t}$ is market log-volatility and $r_{m t}$ is the market return on day $t$.

Squared daily returns were utilized to estimate market volatility values $\left(\sigma_{m t}\right)$, as in Schwert (1989):

$$
\sigma_{m t}^{2}=\sum_{i=1}^{N_{t}}\left(r_{i t}-\overline{r_{t}}\right)^{2}
$$

where $\overline{r_{t}}$ is the average daily market returns and $r_{i t}$ is the daily market returns in month $t$.

Statistically significant $H_{m t}$ is expected in the presence of herd behavior and the degree of $H_{m t}$ shows herding level. If $H_{m t}$ is still significant when these variables are added to the model, there is intentional herding in Borsa Istanbul. Hence, investors follow the others independent from the market volatility and market return. On the other hand, if herding is not found, the existence of spurious herding is emphasized (Hwang \& Salmon, 2004). Furthermore, if the relationship is non-linear, the coefficients of $\log \sigma_{m t}$ and $r_{m t}$ are expected to be negative and significant.

\subsubsection{Beta Herding Model with Fama-French Factors}

Size and book-to-market factors of Fama and French (1993) were taken into account as independent variables and the following equation was analyzed, as in Hwang and Salmon (2004):

$$
\begin{aligned}
& \log \left[\operatorname{Std}_{c}\left(\beta_{i m t}^{b}\right)\right]=\mu_{m}+H_{m t}+c_{m 1} \log \sigma_{m t}+c_{m 2} r_{m t}+c_{m 3} S M B_{t}+c_{m 4} H M L_{t}+v_{m t} \\
& H_{m t}=\emptyset_{m} H_{m t-1}+\eta_{m t}
\end{aligned}
$$

where $\log \sigma_{m t}$ is market log-volatility and $r_{m t}$ is market return. Besides, $S M B_{t}$ represents size and $H M L_{t}$ represents book-to-market factor at time $t$ on Equation 11.

To estimate $S M B_{t}$ and $H M L_{t}$ values, six size-book-to-market portfolios were constructed, as in Fama and French (1993). Firstly, all stocks were divided as small and big, based on their size values, and then bookto-market values were divided as the bottom (30\%), the middle $(40 \%)$, and the top $(30 \%)$. The stocks with the negative book values were not included, following Fama and French (1993).

In case of herding, $H_{m t}$ is expected to be still significant, when the size and book-to-market ratio are added and under the circumstances, investors exhibit intentional herding rather than spurious herding. Therefore, it can be concluded that investors exhibit mimicking behavior independent from these factors. Furthermore, negative coefficients of $S M B_{t}$ and $H M L_{t}$ indicate a non-linear relation between Fama-French factors and herding.

\section{Empirical Findings}

Table 1 presents the descriptive statistics of the variables on daily basis, covering the period from $4^{\text {th }}$ January 2010 to $30^{\text {th }}$ November 2020.

The results show that there are 4231 observations. Logarithms of cross-sectional standard deviation range between 2.0320 and -0.6411 with the highest standard deviation of 0.6087 , and $H_{m t}$ ranges between 0.0004 and -0.0001 with the lowest standard deviation of 0.0001 . Additionally, maximum and minimum values of the market return $\left(r_{m t}\right)$ are reported as 0.0461 and -0.0498 with a standard deviation of 0.0171 . Maximum and minimum values of the market volatility $\left(\log \sigma_{m t}\right)$ are also reported as 0.1179 and 0.0450 with a higher standard deviation of 0.0179. It is also seen from Table 1 that $H M L_{t}$ has the highest value of 0.0636 and the lowest value of -0.0664 with the higher standard deviation of 0.0251 . 
Table 1. Descriptive Statistics

\begin{tabular}{lcccccccc}
\hline & Mean & Median & Maximum & Minimum & $\begin{array}{c}\text { Std. } \\
\text { Dev. }\end{array}$ & Skewness & Kurtosis & Obs. \\
\hline $\log \left[\operatorname{Std}_{c}\left(\boldsymbol{\beta}^{\left.\left.\mathbf{b}_{\mathrm{imt}}\right)\right]}\right.\right.$ & 0.4118 & 0.6510 & 2.0320 & -0.6411 & 0.6087 & -0.1228 & -1.0357 & 4231 \\
$\mathbf{H}_{\mathrm{mt}}$ & -0.0001 & 0.0001 & 0.0004 & -0.0001 & 0.0001 & -0.1335 & -1.0376 & 4231 \\
$\log \sigma_{\mathrm{mt}}$ & 0.0742 & 0.0714 & 0.1179 & 0.0450 & 0.0179 & 0.7401 & -0.1648 & 4231 \\
$\mathbf{r}_{\mathrm{mt}}$ & -0.0006 & 0.0010 & 0.0461 & -0.0498 & 0.0171 & -0.0099 & 0.4973 & 4231 \\
SMB $_{t}$ & 0.0003 & 0.0003 & 0.0792 & -0.0641 & 0.0161 & 0.6477 & 7.2252 & 4231 \\
$\mathbf{H M L}_{t}$ & 0.0002 & 0.0003 & 0.0636 & -0.0664 & 0.0251 & -0.0224 & 2.1578 & 4231 \\
\hline
\end{tabular}

On the other hand, $S M B_{t}$ ranges between 0.0792 and -0.0641 . Table 1 also reports that the higher standard deviation value is consistent with the higher mean value of logarithms of cross-sectional standard deviation. It indicates that this variable deviates from the average value more than the others, as in Akçaalan et al. (2020).

Before predicting the results of linear regression, the estimated regression coefficients were adjusted for stationary, normality, multicollinearity, autocorrelation and heteroscedasticity. Table 2 reports the correlation matrix examining the multicollinearity of the variables. Accordingly, while a positive correlation $(0,3333)$ was observed between logarithms of cross-sectional standard deviation and market return, a negative correlation $(-0,3440)$ was observed between market volatility. Thus, it can be concluded that when logarithms of cross-sectional standard deviation increase, the return of the BIST 100 index increases, and market volatility decreases. Furthermore, the correlation between all the variables is below $50 \%$, indicating no multicollinearity problem among variables.

Table 2. Correlation Matrix

\begin{tabular}{|c|c|c|c|c|c|c|}
\hline & $\log \left[\operatorname{Std}_{c}\left(\beta^{b_{i m t}}\right)\right]$ & $\mathbf{H}_{\mathrm{mt}}$ & $\log \sigma_{m t}$ & $r_{m t}$ & $\mathrm{SMB}_{\mathrm{t}}$ & $H M L_{t}$ \\
\hline $\log \left[\operatorname{Std}_{c}\left(\beta^{b}{ }_{i m t}\right)\right]$ & 1.0000 & 0.1000 & -0.3440 & 0.3333 & 0.0539 & -0.0228 \\
\hline$H_{m t}$ & 0.1000 & 1.0000 & -0.3460 & 0.3342 & 0,0537 & -0.0229 \\
\hline $\log \sigma_{m t}$ & -0.3440 & -0.3460 & 1.0000 & -0.1036 & -0.0092 & 0.0023 \\
\hline$r_{m t}$ & 0,3333 & 0.3342 & -0.1036 & 1.0000 & 0.1057 & -0.0261 \\
\hline $\mathrm{SMB}_{\mathrm{t}}$ & 0.0539 & 0,0537 & -0.0092 & 0.1057 & 1.0000 & -0.2525 \\
\hline HMLt & -0.0228 & -0.0229 & 0.0023 & -0.0261 & -0.2525 & 1.0000 \\
\hline
\end{tabular}

After the preliminary analyses, regression analysis was conducted for the "whole period", "no pandemic period", "pandemic period", respectively. The "whole period" includes daily data from January 2010 to November 2020. After measuring the existence of herd behavior on BIST 100 index for the "whole period", then "no pandemic period" and "pandemic period" were analyzed. While "no pandemic period" covers the period from January 2010 to $10^{\text {th }}$ of March 2020, "pandemic period" includes the data starting with $11^{\text {th }}$ of March 2020. Because the World Health Organization declared Covid-19 as a worldwide pandemic on March 11.

Table 3 exhibits the regression results based on the standard state-space model for "whole period", "no pandemic period", and "pandemic period". Accordingly, a significant coefficient of $H_{m t}$ provided evidence of herding at a rate of $46.76 \%$ for the "whole period", $45.40 \%$ for the "no pandemic" period. Table 3 also reports stronger evidence of herding for the "pandemic period" with the $H_{m t}$ of $67.28 \%$. The results support the findings of Caporale et al. (2008), Qurdo et al. (2013), and Durukan et al. (2017) that detect herding more during market stress days. The signal-proportion value also states that herding explains around $54 \%, 59 \%$, and $52 \%$ of the total variability in cross-sectional volatility of beta coefficients, respectively. F value of each model verifies the validity at the $1 \%$ level. 
Table 3. Regression Results

\begin{tabular}{llll}
\hline & Whole Period & No Pandemic Period & Pandemic Period \\
\hline Obs. & 4231 & 4051 & 180 \\
$\mathbf{H}_{\mathrm{mt}}$ & $(0.4676)^{* * *}$ & $(0.4540)^{* * *}$ & $(0.6728)^{* * *}$ \\
$\mathbf{F}$ & $(10301.65)^{* * *}$ & $(12919.69)^{* * *}$ & $(4463.40)^{* * *}$ \\
Proportion of Signal & $(0.5375)$ & $(0.5786)$ & $(0.5222)$ \\
\hline
\end{tabular}

* Significance at $10 \%,{ }^{* *}$ Significance at $5 \%,{ }^{* * *}$ Significance at $1 \%$.

Note: The proportion of signal value was estimated by dividing the $\sigma_{m n}$ by $\log \left[\operatorname{Std}_{c}\left(\beta_{i m t}^{b}\right)\right]$, as in Gavriilidis et al. (2013).

When the variables of $\log \sigma_{m t}$ and $r_{m t}$ were taken into account, $H_{m t}$ was still significant for all the periods. Thus, investors do not imitate the others because of publicly known information. The results support the existence of intentional herding, as in Messis et al. (2014). The coefficient of $H_{m t}$ also indicated stronger evidence on herding with a value of $73.04 \%$ for the "pandemic period". F values of the state space models are significant to show the validity of the models. The regression results of Equation 8 are reported in Table 4.

Table 4. Regression Results with Market Volatility and Market Return

\begin{tabular}{llll}
\hline & Whole Period & No Pandemic Period & Pandemic Period \\
\hline Obs. & 4231 & 4051 & 180 \\
$\mathbf{H}_{\mathrm{mt}}$ & $(0.4679)^{* * *}$ & $(0.4535)^{* * *}$ & $(0.7304)^{* * *}$ \\
$\log \boldsymbol{\sigma}_{\mathrm{mt}}$ & $(0.0948)$ & $(-0.0679)^{* * *}$ & $(0.0477)$ \\
$\mathbf{r}_{\mathrm{mt}}$ & $(-0.0693)^{*}$ & $(-0.0438)^{*}$ & $(-0.0717)$ \\
$\mathbf{F}$ & $(34468.49)^{* * *}$ & $(9362.6)^{* * *}$ & $(9270.02)^{* * *}$ \\
Proportion of Signal & $(0.5468)$ & $(0.5918)$ & $(0.5114)$ \\
\hline
\end{tabular}

* Significance at $10 \%,{ }^{* *}$ Significance at $5 \%,{ }^{* * *}$ Significance at $1 \%$.

Note: The proportion of signal value was estimated by dividing the $\sigma_{m n}$ by $\log \left[\operatorname{Std}_{c}\left(\beta_{i m t}^{b}\right)\right]$, as in Gavriilidis et al. (2013).

As exhibited in Table 5, size and value factors were included in the analysis and analyzed by utilizing Equation 11. Accordingly, the higher herding level (79.33\%) was found for the pandemic period and the coefficient of $H_{m t}$ was still significant. Thus, there was intentional herding, supporting the results of Özsu (2015). F values provided evidence of the validity of the models. Total variability in cross-sectional volatility of beta coefficients was explained by herding at a rate of $54.52 \%$ for the "whole period", $49.58 \%$ for the "no pandemic period", and $44.20 \%$ for the "pandemic period".

Table 5. Regression Results with Fama-French Factors

\begin{tabular}{llll}
\hline & Whole Period & No Pandemic Period & Pandemic Period \\
\hline Obs. & 4231 & 4051 & 180 \\
$\mathbf{H}_{\mathrm{mt}}$ & $(0.4679)^{* * *}$ & $(0.4535)^{* * *}$ & $(0.7933)^{* * *}$ \\
$\log \sigma_{\mathrm{mt}}$ & $(0.0712)$ & $(-0.0683)^{* * *}$ & $(0.0196)^{* * *}$ \\
$\mathbf{r}_{\mathrm{mt}}$ & $(-0.0708)^{*}$ & $(-0.0436)^{*}$ & $(-0.0381)$ \\
$\mathrm{SMB}_{\mathrm{t}}$ & $(0.0241)$ & $(0.0129)$ & $(0.0139)$ \\
$\mathrm{HML}_{\mathrm{t}}$ & $(-0.0962)$ & $(-0.0117)$ & $(0.0512)$ \\
$\mathbf{F}$ & $(5719.6)^{* *}$ & $(7864.91)^{* * *}$ & $(9277.50)^{* * *}$ \\
Proportion of Signal & $(0.5452)$ & $(0.4958)$ & $(0.4420)$ \\
\hline
\end{tabular}

* Significance at $10 \%,{ }^{* *}$ Significance at $5 \%,{ }^{* * *}$ Significance at $1 \%$.

Note: The proportion of signal value was estimated by dividing the $\sigma_{m n}$ by $\log \left[\operatorname{St} d_{c}\left(\beta_{i m t}^{b}\right)\right]$, as in Gavriilidis et al. (2013). 


\section{Conclusion}

Behavioral finance has grown in the late 1980s by challenging the traditional assumptions of efficient market hypothesis. As a result of unexpected market events, the irrationality of investors and inefficiency of the markets have been observed and thus, researchers have placed a focus on investor psychology on financial decisions and stock market anomalies in financial markets. Herd behavior seems such an anomaly that is referred to as imitating others even they have information directing them to behave as different (Banerjee, 1992: 798). In financial markets, it is referred to as buying (selling) the same stocks that the others buy (sell) (Zhou \& Lai, 2009: 389).

In this study, herd behavior was measured based on the state-space model utilizing cross-sectional volatility of the beta coefficients in the Covid-19 era. To compare the results of the "pandemic period", "no pandemic period", and "whole period", daily data was used covering the years from 2010 to 2020 . The results supported existence of herd behavior among investors trading on Borsa Istanbul and stronger evidence of herding was found for the "pandemic period". However, investors may act in the same way in response to the public announcements and thus, herding may be spurious. The methodology developed by Hwang and Salmon (2004) provides to examine whether herding is intentional. Within this context, market volatility, market return, size and value factors of the Fama-French model were included to differentiate intentional herding from spurious herding. As a result, intentional herding was found among investors in Borsa Istanbul. Thus, investors herd after observing others, rather than following the public information.

Herding can be explained by information acquisition under the global pandemic of Covid-19 in Borsa Istanbul. Wang (2008) states that obtaining information is difficult and expensive in developing markets, instead, exhibiting herd behavior is relatively cheap and easy. Thus, investors may prefer to imitate the others in Borsa Istanbul which is a developing market. Furthermore, institutional investors have more information about other investors and have more effect on stock market returns. Based on the existence of herding, it can be said that there may be sufficient institutional investors to affect stock prices in Borsa Istanbul. Additionally, Bikhchandani and Sharma (2000) state that herding is observed more in developing countries because of the effect of foreign investors. Because herding by foreign investors leads to markets being more volatile due to the capital flows in developing countries. Thus, the effect of foreign investors may also be observed in Borsa Istanbul.

Although herd behavior was investigated in many studies in Borsa Istanbul, the studies based on the methodology of cross-sectional volatility of beta coefficients are relatively less. Even if this method was used, the studies testing intentional herding and using Fama-French factors are quite limited. Hence, this study is one of the first comprehensive attempts to test the existence of intentional herding in Borsa Istanbul, by including market volatility, market return, and Fama-French factors. This is also the first study examining herd behavior in Borsa Istanbul in the Covid-19 era.

The findings of this study are expected to be useful for investors who trade on Borsa Istanbul. It also contributes to the herd behavior literature by looking from a different perspective and being a reference for further studies. However, there are a few limitations of the study. The first limitation is that macroeconomic variables could not be included. Because the daily data is unavailable on the website of the Central Bank of Turkey. Secondly, the direction of herding could not be examined. Because it is not possible to find it by applying the beta herding model. Within this context, monthly macroeconomic variables can be taken into account to evaluate intentional herd behavior among investors. Moreover, the direction of herding could be examined by Lakonishok, Shleifer and Vishny (LSV) measure in further studies. To evaluate herd behavior by examining the effects of earlier financial crises on stock market returns might also be profitable in terms of the comparison of the results. 


\section{Declarations and Disclosures}

Ethical Responsibilities of Authors: The author of this article confirms that her work complies with the principles of research and publication ethics.

Conflicts of Interest: No potential conflict of interest was reported by the author.

Funding: The author received no financial support for the preparation and/or publication of this article.

Author Contributions: The author confirms sole responsibility for conceptualization and design, data collection, analysis of data and interpretation of results, writing the first draft of the manuscript, and review and editing.

Plagiarism Checking: This article was screened for potential plagiarism using a plagiarism screening program.

\section{References}

Akçaalan, E., Dindaroğlu, B., \& Binatlı, A. O. (2020). International investors, volatility, and herd behavior: Borsa Istanbul, 2001-2016. International Journal of Economics and Innovation, 6(2), 247-259.

Altay, E. (2008). Sermaye piyasasında sürü davranışı: IMKB'de piyasa yönünde sürü davranışının analizi. BDDK Bankacılık ve Finansal Piyasalar, 2(1), 27-58.

Angela-Maria, F., Maria, P. A., \& Miruna, P. M. (2015). An empirical investigation of herding behavior in CEE stock markets under the global financial crisis. Procedia Economics and Finance, 25, 354-361.

Asiltürk, A. (2021). Türkiye'de Covid-19 pandemisinin işletmelerde kriz yönetimi üzerine etkileri: 2020 yılı araştırmaları üzerinden bir değerlendirme. Turkish Studies - Economy, 16(1), 67-81.

Baker, M., \& Wurgler, J. (2006). Investor sentiment and the cross-section of stock returns. The Journal of Finance, 61(4), 1645-1680.

Banerjee, A. V. (1992). A simple model of herd behavior. The Quarterly Journal of Economics, 107(3), 797-817.

Barber, B. M., \& Odean, T. (2007). All that glitters: The effect of attention and news on the buying behavior of individual and institutional investors. The Review of Financial Studies, 21(2), 785-818.

Barberis, N. C., \& Thaler, R. H. (2003). A survey of behavioral finance. Handbook of the Economics of Finance (pp. 10531128). North-Holland: Elsevier.

Bikhchandani, S., \& Sharma, S. (2000). Herd behavior in financial markets: A review. IMF Working Paper.

Calap, A. (2021). Koronavirüs salgının rekabetçi büyük güçler arasındaki ilişkilere etkisi. Turkish Studies - Economy, 16(1), 105-139.

Caporale, G. M., Economou, F., \& Philippas, N. (2008). Herding behavior in extreme market conditions: The case of Athens Stock Exchange. Economics Bulletin, 7(17), 1-13.

Carlson, M. (2006). A brief history of the 1987 Stock Market Crash with a discussion of the Federal Reserve Response. Finance and Economics Discussion Series.

Chang, E. C., Cheng, J. W., \& Khorana, A. (2000). An examination of herd behavior in equity markets: An international perspective. Journal of Banking and Finance, 24(10), 1651-1679.

Chen, N. K. (2001). Asset price fluctuations in Taiwan: Evidence from stock and real estate prices 1973 to 1992 . Journal of Asian Economics, 12(2), 215-232.

Chen, G., Rui, O. M., \& Xu, Y. (2003). When will investors herd: Evidence from the Chinese Stock Markets. Working Paper, University of Texas, Dallas.

Christie, W. G., \& Huang, R. D. (1995). Following the pied piper: Do individual returns herd around the market. Financial Analysts Journal, 51(4), 31-37.

Demir, N. S., Mahmud, F., \& Solakoglu, M. N. (2014). Sentiment and beta herding in Borsa Istanbul (BIST). In J. A. Batten and N. F. Wagner (Ed.), Risk management post-financial crisis: A period of monetary easing (pp. 389-400). United Kingdom: Emerald Group Publishing Limited.

Demirer, R., Kutan, A. M., \& Chen, C. D. (2010). Do investors herd in emerging stock markets?: Evidence from the Taiwanese Market. Journal of Economic Behavior and Organization, 76(2), 283-295.

Durukan, M. B., Özsu, H. H., \& Can Ergün, Z. (2017). Financial crisis and herd behavior: Evidence from the Borsa Istanbul. In F. Economou, K. Gavriilidis, G. N. Gregoriou and V. Kallinterakis (Ed.), Handbook of investors' behavior during financial crises (pp. 203-217). United Kingdom: Academic Press, Elsevier.

Fama, E. F. (1965). Random walks in stock market prices. Financial Analysts Journal, 21(5), 55-59. 
Fama, E. F., \& French, K. R. (1993). Common risk factors in the returns on stocks and bonds. Journal of Financial Economics, 33(1), 3-56.

Gavriilidis, C., Kallinterakis, V., \& Micciullo, P. (2007). The Argentine crisis: A case for herd behaviour? Working Paper.

He, Q., Liu, J., Wang, S., \& Yu, J. (2020). The impact of Covid-19 on stock markets. Economic and Political Studies, 8(3), 1-14.

Hassairi, S. A., \& Viviani, J. L. (2011). Herd behavior and market stress: The case of four European countries. International Business Research, 4(3), 53-67.

Hwang, S., \& Salmon, M. (2004). Market stress and herding. Journal of Empirical Finance, 11(4), 585-616.

Kalman, R. E. (1960). A new approach to linear filtering and prediction problems. Journal of Basic Engineering, 82(1), 3545.

Kalman, R. E., \& Bucy, R. S. (1961). New results in linear filtering and prediction theory. Journal of Basic Engineering, 83(1), 95-108.

Lai, M., \& Lau, S. (2004). Herd behavior and market stress: The case of Malaysia. Academy of Accounting and Financial Studies Journal, 8(3), 85-101.

Malkiel, B. G. (2003). The efficient market hypothesis and its critics. Journal of Economic Perspectives, 17(1), 59-82.

Messis, P., Zapranis, A., \& Kollias, C. (2014). Herding towards higher moment CAPM, contagion of herding and macroeconomic shocks: Evidence from five majör developed markets. Journal of Behavioral and Experimental Finance, 4(4), 1-13.

Montier, J. (2002). Behavioral finance: Insights into irrational minds and markets. United States of America: Wiley Finance.

Ourda, M., El Bouri, A., \& Bernard, O. (2013). Herding behavior under markets condition: Empirical evidence on the European financial markets. International Journal of Economics and Financial Issues, 3(1), 214-228.

Özsu, H. H. (2015). Empirical analysis of herd behavior in Borsa Istanbul. International Journal of Economic Sciences, 4(4), 27-52.

Pop, R. E. (2012). Herd behavior towards the market index: Evidence from Romanian Stock Exchange. Munich Personel RePEc Archive, 51595(26).

Ritter, J. (2003). Behavioral finance. Pacific-Ocean Finance Journal, 11(4), 429-437.

Schwert, G. W. (1989). Why does stock market volatility change over time? The Journal of Finance, 44(5), 1115-1153.

Seetharam, Y., \& Britten, J. (2013). An analysis of herding behavior during market cycles in South Africa. Journal of Economics and Behavioral Studies, 5(2), 89-98.

Shleifer, A., \& Summers, L. H. (1990). The noise trader approach to finance. Journal of Economic Perspectives, 4(2), 1933.

Solakoğlu, M. N., \& Demir, N. (2014). Sentimental herding in Borsa Istanbul: Informed versus uninformed. Applied Economics Letters, 21(14), 965-968.

Stone, D., \& Ziemba, W. T. (1993). Land and stock prices in Japan. The Journal of Economic Perspectives, 7(3), $149-165$.

Topcu, M., \& Gülal, Ö. S. (2020). The impact of Covid-19 on emerging stock markets. Finance Research Letters, 36, 1-4.

Wang, D. (2008). Herd behavior towards the market index: Evidence from 21 financial markets. IESE Business School Working Paper.

Wermers, R. (1999). Mutual fund herding and the impact on stock prices. The Journal of Finance, 54(2), $581-622$.

Zhou, R., \& Lai, R. (2009). Herding and information-based trading. Journal of Empirical Finance, 16(3), 388-393. 